К.С. ІЛЬОНОК

Херсонський національний технічний університет

\title{
ДОСЛІДЖЕНЯЯ РИНКУ СПОЖИВАЧІВ ЖІНОЧОГО ОДЯГУ РІЗНИХ ЦІНОВИХ СЕГМЕНТІВ
}

\begin{abstract}
У сучасному світі, сконцентрованому на споживачеві, його поведінка набуває вирімального значення, щзо помітно посилює вплив на діяльність організацій будь-якого типу та вимагає від них подальших розробок методів впливу на споживача із врахуванням його вподобань. У даній роботі проведено дослідження вподобань споживачів з різним рівнем доходів щуодо вибору жіночого одягу. У зв'язку з ускладненням структури потреб населення адресний підхід до прочесу проектування одягу $\epsilon$ найважливішою умовою забезпечення збуту продукиї. В изьому випадку при проектуванні одягу підприємства повинні враховувати чітко визначений сегмент ринку, його потреби і очікування. Цільова аудиторія - жінки у вічі від 20 до 55 років і стариі, сочіальний стан - студенти, фахівці, керівники середньої ланки, начальники відділів, керівники організацій. Вимоги спожсияачів різних цінових сегментів до одягу мають не рівнозначні особливості. Крім того, їх відмінності в освіті, доходах, професійній діяльності є корисними орієнтирами для виробничтва одягу та його реалізаціі. Виділено три основних цінові сегменти ринку споживачів з низьким, середнім та високим рівнем доходів щодо жіночого одягу та визначено значимість критерїв вибору для кожного з них. Так, для споживачів низького цінового сегмента одним з найбільш важливих критеріїв вибору жакета є ичіна виробу, для середнього ичінового сегмента - якість посадки жакета і для високого ијінового сегмента - якість виготовлення та посадки жакета. Для виявлення значущцості критерїв цінової групи виробу було проведено експертне опитування. Найбільш значимим критерієм для жіночого верхнього одягу при формуванні иінової групи $\epsilon$ вибір матеріалу верху. Тому чітка орієнтація на споживчі вимоги повинна здійснюватися на кожному етапі проектування виробу. Запропоновано під час виробництва одягу для певного цүінового сегменту враховувати вимоги споживачів цього сегменту.
\end{abstract}

Ключові слова: ичіновий сегмент, ринок, споживач, якість, критерій.

В.В. ЕВТУШЕНКО

Херсонский национальный технический университет ORCID: 0000-0001-6545-7755

И.А. РУДЕНКО

Херсонский национальный технический университет ORCID: 0000-0001-9964-6386

К.С. ИЛЬОНОК

Херсонский национальный технический университет

\section{ИССЛЕДОВАНИЕ РЫНКА ПОТРЕБИТЕЛЕЙ ЖЕНСКОЙ ОДЕЖДЫ РАЗНЫХ ЦЕНОВЫХ СЕГМЕНТОВ}

В современном мире, сконцентрированном на потребителе, его поведение приобретает решающее значение, заметно усиливает влияние на деятельность организаций любого типа и требует от них дальнейших разработок методов воздействия на потребителя с учетом его предпочтений. В данной работе проведено исследование предпочтений потребителей с разным уровнем доходов по выбору женской одежды. В связи с усложнением структуры потребностей населения адресный подход $\kappa$ прочессу проектирования одежды является важнейшим условием обеспечения сбыта продукции. В этом случае при проектировании одежды предприятия должны учитывать четко определенный сегмент рынка, его потребности и ожидания. Целевая аудитория - женщины в возрасте от 20 до 55 лет и старше, сочиальное положение - студенты, специалисты, руководители среднего звена, начальники отделов, руководители организаций. Требования потребителей различных иееновых сегментов к одежде имеют не равнозначны особенности. Кроме того, их различия в образовании, доходах, профессиональной деятельности являются полезными ориентирами для производства одежды и ее реализации. Выделены три основных цүеновых сегмента рынка потребителей с низким, средним и 
высоким уровнем доходов относительно женской одежды и определена значимость критериев выбора для каждого из них. Так, для потребителей низкого изенового сегмента одним из самых важных критериев выбора жакета является иена изделия, для среднего иеенового сегмента - качество посадки жакета и для высокого ценового сегмента - качество изготовления и посадки жакета. Для выявления значимости критериев ценовой группы изделия был проведен экспертный опрос. Наиболее значимым критерием для женской верхней одежды при формировании ценовой группь является выбор материала верха. Поэтому четкая ориентация на потребительские требования должна осуществляться на каждом этапе проектирования изделия. Предложено при производстве одежды для определенного ценового сегмента учитывать требования потребителей этого сегмента.

Ключевые слова: иченовой сегмент, рынок, потребитель, качество, критерий.

V.V. YEVTUSHENKO

Kherson National Technical University ORCID: 0000-0001-6545-7755

I.A. RUDENKO

Kherson National Technical University ORCID: 0000-0001-9964-6386

K.S. IL'ONOK

Kherson National Technical University

\section{RESEARCH OF WOMEN'S CLOTHES CONSUMERS MARKET OF DIFFERENT PRICE SEGMENTS}

In today's consumer-centered world, its behavior is crucial, which significantly increases the impact on the activities of organizations of any type and requires them to further develop methods of influencing the consumer, taking into account their preferences. In this paper, a survey of consumer preferences with different income levels regarding women's clothing choices is conducted. Due to the complexity of the structure of the needs of the population, the targeted approach to the process of designing clothes is the most important condition for ensuring product sales. In this case, when designing clothes, businesses should take into account a well-defined market segment, its needs and expectations. Target audience - women aged 20 to 55 and older, social status - students, professionals, middle managers, heads of departments, heads of organizations. Consumer requirements of different price segments for clothing have different features. In addition, their differences in education, income, professional activity are useful guidelines for the production of clothing and its implementation. The three main price segments of the low, middle and high income consumer market are identified for women's clothing and the significance of the selection criteria for each is determined. Thus, for consumers of the low price segment one of the most important criteria for choosing a jacket is the price of the product, for the middle price segment - the quality of fit of the jacket and for the high price segment - the quality of manufacture and fit of the jacket. An expert survey was conducted to identify the significance of the product price criteria. The most significant criterion for women's outerwear when pricing is the choice of the material of the top. Therefore, a clear focus on consumer requirements should be at every stage of product design. It is suggested that, when producing clothing for a particular price segment, the requirements of the customers in that segment should be taken into account.

Keywords: price segment, market, consumer, quality, criterion.

\section{Постановка проблеми}

В умовах конкурентного середовища якість товару має особливе значення та стала одним із засобів впливу на споживача. У створенні нових видів продукції особлива увага приділяється зовнішнім ознакам виробу, на які в першу чергу звертає увагу споживач. Вимоги споживачів різних цінових сегментів до одягу мають не рівнозначні особливості. Тому доцільним є проведення маркетингових досліджень для визначення груп споживачів із подібними вподобаннями. Необхідно виявити особливості вподобань споживачів з низьким, середнім та високим рівнем доходів щодо жіночого одягу та встановити значимість критеріїв, що впливають на формування цінової групи виробів.

\section{Аналіз останніх досліджень і публікацій}

Дослідженням ринку споживачів, особливостями його формування та розвитку займалися ряд вчених. Зокрема, сегментуванню ринку за групами споживачів в умовах перенасиченості ринку товарів легкої промисловості, приділено увагу в дослідженнях С.С. Гаркавенко [1]. Вивченням основних чинників впливу на споживчу поведінку в сучасних умовах займалася О.В. Свтушевська [2]. В.А. Нікульча та Ю.Б. Чаплінський досліджували маркетингові складові формування купівельної поведінки споживачів [3].

Недостатньо уваги приділено дослідженням діапазону цін на верхній жіночий одяг i вподобанням споживачів даних сегментів. 


\section{Формулювання мети дослідження}

Метою дослідження є аналіз сегментів жіночого одягу (жакетів) різних цінових категорій. Викладення основного матеріалу дослідження

В умовах постійно мінливої кон'юнктури ринку, а також скорочення виробничого циклу, результати роботи швейних підприємств залежать від того, наскільки точно і правильно вибраний сегмент ринку для проектування одягу. У зв’язку з ускладненням структури потреб населення адресний підхід до процесу проектування одягу є найважливішою умовою забезпечення збуту продукції. В цьому випадку при проектуванні одягу підприємства виявляють чітко визначений сегмент ринку, його потреби і очікування. На сьогодні у всьому світі провідну роль при плануванні асортименту відіграють маркетингові дослідження [4].

Маркетингове дослідження складається 3 п’яти основних етапів (рис. 1), з яких визначальним є виявлення проблеми і формування цілей.

Цілі можуть бути пошуковими, описовими і експериментальними, і їх досягнення відбувається шляхом збору, переробки первинної та вторинної інформації.

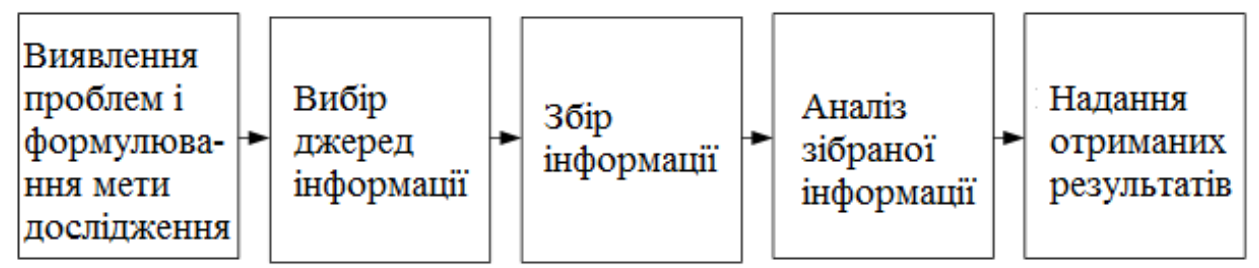

Рис. 1. Схема основних етапів маркетингових досліджень

В рамках даної роботи проведено аналіз сегментів жіночого одягу (жакетів) різних цінових категорій. Для споживачів з низьким, середнім і високим рівнем доходу переваги значно відрізняються за моделями, конструктивними рішеннями i матеріалами, 3 яких виготовляється виріб, якістю виготовлення. Метою даного дослідження було виявлення діапазону цін на жіночі жакети різних цінових сегментів м. Херсона і переваг споживачів даних сегментів.

Маркетингове дослідження проводилося методом структурованого опитування-анкетування. Анкети заповнювалися зі слів респондентів і самостійно опитуваними в разі інтернет-розсилання.

Ефективність проведення опитування багато в чому залежить від визначення вибірки. Вибірка кількісний параметр вибіркової сукупності, кількість одиниць спостереження, що підлягають вивченню (кількість респондентів).

Репрезентативність вибірки забезпечувалася імовірнісним підходом, при якому відбір респондентів здійснювався за суб'єктивними критеріями - жінки у віці від 20 до 55 років і старші, соціальний стан - студенти, фахівці, керівники середньої ланки, начальники відділів, керівники організацій.

Достовірність висновків про закономірності соціальних явищ залежить від якості проведеної вибірки. При науково обгрунтованому визначенні чисельності опитуваних осіб вибіркова сукупність служить моделлю генеральної сукупності в тому випадку, якщо в ній 3 точністю відтворюється статистичний розподіл, тобто вибірка в зменшеному розмірі передає різноманітність за допомогою показника дисперсії розподілу осіб генеральної сукупності.

Сукупність індивідів, для яких потрібно встановити закон розподілу випадкової величини та його параметри за однією або декількома характеристиками, називається генеральною сукупністю, а ії частина, результати емпіричного дослідження якої щодо закону і параметрів розподілу за цими характеристиками поширюються на всю генеральну сукупність, називається вибірковою сукупністю.

Якість вибірки оцінюється за двома показниками: репрезентативності та надійності, таким чином, щоб розбіжність між величинами вибіркової і генеральної середньої не перевищує допустимої величини граничної помилки вибірки.

Вибірка, може бути повторною і без повторною. При повторній вибірці один і той же елемент може потрапити в вибіркову сукупність кілька разів, так як після випробування цей елемент повертається в генеральну сукупність і може потрапити до вибірки повторно.

У без повторній вибірці кожен елемент генеральної сукупності може потрапити в вибіркову сукупність тільки один раз, оскільки після випробування він не повертається в генеральну сукупність.

В даному маркетинговому дослідженні використовується без повторна вибірка, так як опитування респондента здійснюється один раз.

В процесі проведення досліджень приймали участь респонденти, вік більшої частини яких - $30 \%$ знаходиться в діапазоні до 24 років, 25\% - 25-34 років, 18\% - 35-44 роки, 19\% - 45-54 років і 8\% - 55 років i старші. 
Розподіл опитаних за соціальним статусом склало: 54\% - фахівці - працівники, зайняті в комерційній структурі, 17\% - студенти різних навчальних закладів, $10 \%$ - працівники державних структур і служб, 16\% - респонденти, які займаються індивідуальною комерційної діяльністю, $3 \%$ пенсіонери.

Оскільки рівень життя і цін в різних регіонах країни відрізняються один від одного, тому доцільно при визначенні цінових сегментів ринку жіночого одягу враховувати платоспроможний попит населення.

Низький ціновий сегмент ринку орієнтований на споживачів 3 невеликим доходом i представлений недорогим одягом, ціна якого утримується на рівні речових ринків. Споживачі цієї групи мають раціональний підхід до вибору одягу, віддають перевагу більш практичним і універсальним моделям, відповідним до різних ситуацій.

Опитування споживачів за критеріями вибору жакетів показав, що для споживачів низької цінової групи визначальним є оптимальне співвідношення ціна-якість: при невисокій вартості товару повинні бути достатній рівень якості виготовлення та посадка. В результаті опитування $30 \%$ респондентів вказали ціну виробу в якості головного критерію вибору жакета, 20\% - якість посадки виробу на фігурі, 19\% - якість виготовлення виробу, 11\% - волокнистий склад матеріалу, 3 якого виготовлений жакет, 12\% - модельні особливості (конструктивне рішення) жакета, 8\% - бренд (фірмавиробник) жакета.

Така вимога обумовлена тим, що в низькому ціновому сегменті споживачі не можуть дозволити собі часто міняти предмети свого гардероба і підходять до вибору одягу з позиції практичності. При цьому часто доводиться поступатися якістю матеріалу, його волокнистим складом, оскільки дані критерії підвищують вартість продукції.

Вироби, в основному, виконані з матеріалів з великим вмістом синтетичних волокон: від $70 \%$ до 100\%. Вміст натуральних волокон у складі матеріалу не перевищує 30\%.

В середньому сегменті діапазон цін і платоспроможний попит споживачів вищий, ніж в низькому. Споживачами даної групи товарів є жінки у віці від 26 до 45 років, які мають постійний, стабільний заробіток, це жінки, які працюють в середній ланці - всі вони можуть дозволити собі часто відвідувати модні магазини.

Результати опитування показали значимість якості посадки жакета для споживачів середнього цінового сегмента - 25\%, 24\% виділили якість виготовлення головним критерієм вибору жакета, 16\% вказали модельні особливості (конструктивне рішення) жакета, $18 \%$ - вказали волокнистий склад матеріалу, з якого виготовлений жакет, 10\% - ціна виробу і 7\% - бренд (фірма-виробник) жакета.

Відповідати запитам даної категорії споживачів здатні виробники, які динамічно реагують на віяння високої моди. Однак не всі згодні з такою точкою зору, тому що часто швидке копіювання модних моделей, призводить до невисокої якості товару. До того ж покупці вважають за краще купувати одяг не на один сезон, а на більш тривалий термін.

Представники середнього цінового сегмента, на відміну від низького, більш схильні купувати одяг певних брендів. Вміст натуральних волокон, як правило, в складі матеріалу від 40-80\%.

Високий ціновий сегмент має вузьку спрямованість на клас споживачів 3 надзвичайно високими вимогами до одягу. Це жінки, в основному, старші 30 років, з високим рівнем достатку. Перш за все, потрібно відзначити, що дана категорія людей цінує бездоганну якість в усьому: матеріалах, конструкції, обробці. Моделі,які продають спеціалізовані магазини відомих брендів, в повній мірі відповідають даним вимогам. Прихильність споживачів того чи іншого бренду залежить від смаку покупця і орієнтації марки на вікову групу. Вміст натуральних волокон, як правило, в складі матеріалу від 75 до100\%.

Результати опитування споживачів високого цінового сегмента показали значимість якості виготовлення жакета - 25\% і якість посадки - 24\%, 20\% респондентів вказали головним критерієм волокнистий склад матеріалу, з якого виготовлений жакет, 17\% - бренд (фірма-виробник) жакета, 8\% ціна виробу і 6\% - модельні особливості (конструктивне рішення) жакета.

Провівши аналіз переваг споживачів при покупці жакетів та асортименту магазинів жіночого одягу, вдалося виділити три основних цінові сегменти ринку і визначити значимість критеріїв вибору для кожного $з$ них. Так, для споживачів низького цінового сегмента одним з найбільш важливих критеріїв вибору жакета $є$ ціна виробу, для середнього цінового сегмента - якість посадки жакета і для високого цінового сегмента - якість виготовлення і якість посадки жакета.

Вирішуючи питання про відмінність жіночих жакетів, призначених для споживачів 3 різним рівнем доходу необхідно виявити значимість критеріїв, що впливають на формування цінової групи виробів. Тому чітка орієнтація на споживчі вимоги повинна здійснюватися на кожному етапі проектування виробу.

Для виявлення значущості критеріїв цінової групи виробу було проведено експертне опитування серед фахівців швейних підприємств міста Херсона - ТОВ «Швейна фабрика «ВІД», ПП «Швейна фабрика «Юність» та швейна фабрика Херсонського УВП УТОГ. При проведенні опитування, було 
запропоновано дати суб'єктивну оцінку для кожного виду критеріїв таких, як підбір матеріалу верху, вибір конструктивного і технологічного рішення. При цьому найбільш важливий критерій має оцінку $\mathrm{R}=$ 1 , а найменш значимий $\mathrm{R}=3$.

Суми рангових оцінок $\sum_{j=1}^{n} R_{i j}$ кожного експерта однакові і розраховуються за формулою:

$$
\begin{gathered}
\sum_{j=1}^{n} R_{i j}=(1+2+3+\cdots+\mathrm{n})=0,5 \mathrm{n}(\mathrm{n}+1), \text { для } \mathrm{i}=1 \ldots \mathrm{m} \\
\sum_{j=1}^{n} R_{i j}==(1+2+3)=6
\end{gathered}
$$

де n - кількість груп характеристик властивостей критеріїв;

m - кількість експертів.

Вихідна матриця рангів наведена в табл. 1.

Таблиця 1

Вихідна матриця рангів

\begin{tabular}{|c|c|c|c|}
\hline \multirow{2}{*}{ Шифр експерта } & \multicolumn{3}{|c|}{ Рангові оцінки властивостей факторів } \\
\cline { 2 - 4 } & 1 & 2 & 3 \\
\hline 1 & 2 & 1 & 2 \\
\hline 2 & 2 & 2 & 2 \\
\hline 3 & 1 & 3 & 3 \\
\hline 4 & 1 & 2 & 3 \\
\hline 5 & 1 & 1 & 3 \\
\hline 6 & 1 & 3 & 19 \\
\hline 7 & 1 & 2 & 14 \\
\hline
\end{tabular}

Сума рангових оцінок по вертикалі $\mathrm{Sj}$ для кожної групи властивостей критеріїв $\mathrm{Xj}$ розраховується за формулою:

$$
S_{j}=\sum_{j=1}^{n} R_{i j}, \text { для } \mathrm{j}=1 \ldots \mathrm{n}
$$

Для кожної групи властивостей критеріїв $X_{j}$ визначається коефіцієнт значущості за формулою:

$$
Y_{j=\frac{m n-S_{j}}{m n^{2}-m \sum_{j=1}^{n} R_{i j}}}
$$

де $\mathrm{Sj}$ - сума рангових оцінок за вертикаллю

Для визначення узгодженості експертних оцінок за даними рангових оцінок експертів розраховуємо коефіцієнт конкордації W за формулою:

$$
W=\frac{\sum_{j=1}^{n}\left(S_{j}-\bar{S}\right)^{2}}{\frac{1}{12} m^{2}\left(n^{3}-n\right)}
$$

де $\bar{S}$ - середня сума рангів для всіх груп властивостей, що дорівнює

$$
\bar{S}=0,5 \mathrm{~m}(\mathrm{n}+1)
$$

Для оцінки значущості коефіцієнта узгодження знаходимо критерій Пірсона $\gamma^{2}=\mathrm{W}_{\mathrm{m}}(\mathrm{n}-1)$, який зіставляємо з табличним значенням критерію $\gamma^{2}$ при степені свободи $\mathrm{S}=\mathrm{n}-1$.

Отримані коефіцієнти значущості критеріїв наведені в табл. 2.

Таблиця 2

Коефіціснти значущості критеріїв цінової групи жакетів

\begin{tabular}{|l|c|c|}
\hline \multicolumn{1}{|c|}{ Види критеріїв } & Місце критерію & Коефіцієнт значущості \\
\hline Підбір матеріалу верху & 1 & 0,6 \\
\hline Розробка конструктивного рішення & 2 & 0,3 \\
\hline Розробка технологічного рішення & 3 & 0,09 \\
\hline Коефіцієнт конкордації W & & 0,51 \\
\hline Критерій Пірсона $\gamma_{\text {розр. }}^{2}$ & 7,14 \\
\hline Критерій Пірсона $\gamma_{\text {табл. }}^{2}$ & 5,99 \\
\hline
\end{tabular}


3 даних табл. 2 можна зробити висновок, що матеріал верху має найбільший коефіцієнт значущості $(0,6)$ при формуванні цінової групи виробу. Тому важливість дослідження даного критерію $€$ обгрунтованою.

Тому, при виборі матеріалу в процесі підготовки до запуску у виробництво виробів для певного цінового сегмента важливо мати інструмент, який дозволяє визначити, наскільки даний матеріал задовольняє вимогам споживачів певного сегмента 3 урахуванням психометричних особливостей сприйняття якості людиною.

\section{Висновки}

1. За результатами проведених досліджень вдалося виділити три основних цінові сегменти ринку та визначити значимість критеріїв вибору для кожного 3 них. Так, для споживачів низького цінового сегмента одним 3 найбільш важливих критеріїв вибору жакета $є$ ціна виробу, для середнього цінового сегмента - якість посадки жакета і для високого цінового сегмента - якість виготовлення i якість посадки жакета.

2. Встановлено, що матеріал верху жіночого одягу має найбільший коефіцієнт значущості під час формування цінової групи виробу. Тому при виробництві одягу для певного цінового сегменту доцільним є врахування вимог споживачів цього сегменту.

\section{Список використаної літератури}

1. Гаркавенко С.С. Сегментування ринку за групами споживачів як основа формування конкурентоспроможності в умовах перенасиченості ринку взуття / С.С. Гаркавенко // Вісник Хмельницького національного університету. Економічні науки. - №4. Т.4 - Хмельницький. 2010. - C. 214-217

2. Свтушевська О.В. Особливості поведінки споживачів на ринку в сучасних умовах / О.В. Євтушевська // Інвестиції: практика та досвід. - 2016. - № 20. - С. 22-24.

3. Нікульча В.А. Маркетингові складові формування купівельної поведінки споживачів / В.А.Нікульча, Ю.Б. Чаплінський // Вісник Чернівецького торговельно-економічного інституту КНТЕУ. - Чернівці: ЧТЕІ КНТЕУ, 2014. - Випуск IV (56). Економічні науки. - С. 178-185

4. Каменева Н.Г. Маркетинговые исследования: Учеб. пособие / Н.Г. Каменева, В.А. Поляков. - 2-е изд., доп. - М.: Вузовский учебник: НИЦ Инфра-М, 2012. - 368 с.

\section{References}

1. Garkavenko S.S. Market segmentation by consumer groups as the basis of competitiveness formation in the conditions of oversaturation of the shoe market / S.S. Garkavenko // Bulletin of the Khmelnytsky National University. Economic sciences. - №4. Vol.4 - Khmelnitsky. - 2010. - P. 214-217

2. Yevtushevskaya O.V. Peculiarities of consumer behavior in the market in modern conditions / O.V. Yevtushevskaya // Investments: practice and experience. - 2016. - № 20. - P. 22-24.

3. Nikulcha V.A Marketing components of forming consumer buying behavior / V.A. Nikulcha, Yu.B. Chaplinsky // Bulletin of the Chernivtsi Trade and Economic Institute of KNTEU. - Chernivtsi: KNTEU, 2014. - Issue IV (56). Economic sciences. - P. 178-185

4. Kameneva N.G., Polyakov V.A. Marketing Research: Textbook. Allowance. 2nd ed., Ext. Moscow, University textbook: SIC Infra-M, 2012. 368 p. 